\title{
A Connectedness Framework: Breaking the Cycle of Child Removal for Black and Indigenous Children
}

\author{
Yvonne Elder Chase ${ }^{1}\left[\right.$ ] . Jessica Saniguq Ullrich ${ }^{2}$ (])
}

Accepted: 7 November 2021 / Published online: 14 February 2022

(c) The Author(s), under exclusive licence to Springer Nature Switzerland AG 2022

\begin{abstract}
Recent anti-racist, equity, and social justice discourse in child welfare has centered on a restructured, reimagined, or abolished system. We add our scholarship and recommendations to this discourse by focusing on Alaska Native and African American children because these two populations have had an ongoing disproportionate number of children in out-of-home care. We provide an overview of the history that implicates western-based colonial policies and practices. We have also identified how a system invested in child removal is problematic and discuss what attempts have been made to change child welfare. We propose a framework to guide systems change within child welfare that is rooted in connectedness. The hope is that the application of this framework can improve outcomes for children and families of color.
\end{abstract}

Keywords Child welfare reform - Connectedness - Conceptual framework · Systemic racism $\cdot$ Historical trauma

With the witnessed atrocity of George Floyd's death, we were called once again to examine the historical and ever-present injustice of racism within systems and take action to change it. All systems are implicated, including the child welfare system, where Alaska Native/American Indian and Black families have experienced a shared history of forced child removal through either the atrocities of residential boarding schools or slavery and are overrepresented in child welfare services. Racial disproportionality is not by chance, and we need to see the implementation of social justice within child welfare. This paper elucidates historical oppression for Alaska Native/ American Indian (AN/AI) and Black children and families that carries over into the

Yvonne Elder Chase

ymchase@alaska.edu

1 Department of Human Services, University of Alaska Anchorage, 3201 Providence Drive, PSB-218F, Anchorage, AK 99508, USA

2 Department of Social Work, University of Alaska Anchorage, 3201 Providence Drive, PSB-218F, Anchorage, AK 99508, USA 
child welfare system, discusses the policy level attempts to rectify child welfare that have fallen short, presents evidence for the continued need for child welfare reform, and provides a connectedness framework for systems change that can help current efforts to reimagine child welfare.

\section{The History of Child Removal}

\section{Revisiting Years of Slavery}

Throughout recorded history, people have been exterminated, enslaved, and oppressed. The USA, a country that pledged open arms to immigrants, chose not to welcome immigrants of color, but to suppress and oppress them while at the same time removing lands and exterminating the Indigenous populations. The history of this country has been greatly sanitized in the history books, but when we look at the enslavement of Africans and the history of genocide of Native Americans, America is responsible for some of the most gruesome crimes against humanity (DunbarOrtiz, 2014).

The first African slaves were removed from their families, community, and continent and brought to America in 1619, now close to 400 years ago. There are estimates in the millions of the number of Africans who died en route to America (Wolfe, 2021). Messer-Kruse (2020) notes how, "For the first time, the 1619 Project pushed into public view a theory that holds that the architecture of America is built of antiblack racism and that America's evolution was propelled by African American struggles for liberation" (para 16). This type of historical legacy is not easily eliminated and the effects in the everyday lives of African Americans. The literature on cultural trauma has focused on genocide survivors, Indigenous peoples and Holocaust survivors, and post slavery trauma with African Americans. The effects of slavery have been described as post traumatic slave syndrome, or PTSS (Halloran, 2019). Leary (2005) mentioned an example of intuitive responses of African Americans in settings that are mostly white. Leary (2005) described an African American mother waiting in line in a bank and intuitively sending a message to her children to stay close, while a Caucasian mother was also in line and her children could freely explore the waiting room. The historical context of White supremacy and racism teaches children of color that the world is unsafe, and that differential treatment based on skin color is normal. We are forced to take a closer look at US history and reconceptualize the source material that has omitted or reconfigured the experiences of marginalized populations that have led to historical trauma and which continues today.

\section{Residential Boarding Schools}

Native communities in the USA have experienced forced relocation, genocide, and decades of their children being taken. Hundreds of thousands of AN/AI children were forcibly removed from their families to attend boarding schools (National 
Native American Boarding School Healing Coalition, n.d., para. 2). During the boarding school era, the adoption of AN/AI children into non-native families was also promoted by government agencies under the Snyder Act of 1921 without any due process (Cross, 2014). Through The Adoption Project, the Child Welfare League of America supported the adoption of 395 AN/AI children into non-relative homes. CWLA publicly apologized for their involvement in this detrimental process in 2001 (Tribal Law Updates, 2001).

We are still learning about the consequences of spiritual, psychological, emotional, and physical harm that AN/AI children, families, and tribes experienced as a result of the boarding school and adoption era (Cross, 2014; Haaland, 2021). Many AN/AI children that attended boarding school were sexually, emotionally, and physically abused and killed (Hirshberg, 2005; Hopkins, 2013). The discovery of hundreds of Indigenous children's bodies buried at residential schools in Canada has touched on a wound that has been there for generations, and communities are coming together to help address and heal from this traumatic loss and pain (Haaland, 2021). Brave Heart et al. (2011) defined historical trauma as the "cumulative emotional and psychological wounding across generations, including the lifespan, which emanates from massive group trauma" (p. 283). Many AN/AI children adopted into non-native families grew up feeling isolated and unwanted (White Hawk, 2006). These same traumatized AN/AI children grew up without healthy ways to cope and did not learn the tribal parenting practices that sustained children and families for generations (Napoleon, 1996). It is not a chance that Black and AN/AI families are disproportionately involved with child welfare and the historical trauma of child removal problematizes the child welfare's current intervention of child removal to stranger foster care.

\section{Child Protection: Disproportionality}

In Alaska, 2,060 out of 3,166 children in out-of-home care are AN/AI and comprise $65 \%$ of the total number of children in out-of-home care (Office of Children's Services, 2020). These percentages have remained disproportionately high for over a decade (Office of Children's Services, 2020). This is problematic because Alaska Native people comprise approximately $20 \%$ of the general population (State of Alaska Department of Labor, 2019).

National data has similar trends of racial disparities. Wildeman and Emanuel (2014) examined a 10-year period of Adoption and Foster Care Analysis and Reporting System (AFCARS) data and found that cumulative risk of foster care placement was much higher for Black children and Native American children even though placement declined during that time period. While the rate of child abuse in the USA is highest among American Indian or Alaska Native victims with a rate of 14.8 cases per 1,000 children, African American children had the second highest numbers with a rate of 13.8 per 1,000 children (Children's Bureau, 2021). These rates call to question how much bias exists within child welfare workers and whether the substantiation of child maltreatment for AN/AI and Black families is based on 
race (Gottlieb, 2021). Children and families of color continue to be overrepresented in the system, regardless of location.

This stratification of children in out-of-home care is connected to larger systemic issues that intersect with the child welfare system. Issues such as poverty, lack of access to health care, and segregated schools are embedded in White supremacist ideologies and policies that have negatively affected children of color, their families, as well as communities for generations. Banahene and Minka (2018) completed a study focused on the experiences of Black parents in Canada who felt that their parenting was unfairly targeted by the child protection agency staff. The authors noted that "The use of CRT [Critical Race Theory] helps to challenge Child Welfare Agency's claims of neutrality, objectivity, color blindness, and meritocracy that often become camouflages to sustain pro-White hegemony about parenting while ignoring the diverse parenting practices of Blacks (sic.) and Indigenous families." What this study pointed out was the sanctioned regression and imposed silence regarding the parenting practices of parents of color in White settler societies. While this study focused specifically on Canada, it mirrors the experiences of Black parents in the USA (Dettlaff \& Boyd, 2020).

The promotion of wellbeing and prevention of ongoing harm is necessary for the achievement of justice. Powers and Faden (2006) state, "Justice, therefore, requires both obligations to remedy existing systematic patterns of disadvantage that profoundly and pervasively undermine the prospects for wellbeing, as well as prospective obligations to design social institutions and structures in order to prevent such patterns of disadvantage from arising" (p. 72). For too long, Black and Indigenous children and families have suffered from systematic oppressions, despite attempts to remedy and reform these injustices.

\section{The Failure of Policies and Institutions}

\section{Unfollowed Recommendations}

Child protection is a dysfunctional system for marginalized populations because it is a complex system that believes the answers and solutions come from experts outside of families and communities. Over thirty years have passed since the US Advisory Board on Child Abuse and Neglect (USABCAN) issued its first report to Congress and the White House, calling for a national strategy on child abuse and neglect (USABCAN, 1990). Members of that committee had great hopes that their recommendations would be implemented, at least in part, that centers on de-stigmatization, community, and relationships. The USABCAN (1990) was established under the provisions of Public Law 100-294 and the 1988 amendments to the Child Abuse and Treatment Act. In its first report, the USABCAN (1990) produced 31 recommendations that covered a number of areas, including recognizing the national emergency, coordinating efforts, providing leadership, generating knowledge, increasing human resources, providing and improving programs, and planning for the future.

The two most critical recommendations of the USABCAN (1990) that would have paved the way for a "minority-friendly" system were as follows: (1) recognizing the 
national emergency, which included each citizen and each elected official accepting responsibility and acknowledging that the American child protection system needed rehabilitating, and (2) estimating the true costs of repairing a broken system. This final recommendation also called for "a model planning process aimed at generating plans for the coordinated, comprehensive, community-based prevention, identification of abuse and neglect, and for the federal government to take appropriate steps to assure that the model process was implemented throughout the nation" (USABCAN, 1990). Had the recommendations in the USABCAN (1990) report, as well the recommendations in subsequent reports of the USABCAN $(1991,1993)$ ) been implemented, the current system would look much different.

\section{Staffing Shortages}

Retaining staff and especially culturally competent staff continues to be problematic for state and county child protection agencies and is an illustration of the broken system. In the 1990s and continuing into the present day, the tenure of an administrator is about 18 months, but the retention of line staff and supervisors has changed, and not for the better (Guzman et al., 2020). Staff retention appears to be at an all-time low in many states. Lacking any consistency in the worker handling a case causes further disruption and lack of trust for families of color in the child protection system. Kim and Kao (2014) completed a meta-analysis of the literature on turnover intention predictors of public child welfare caseworkers. While some of the variables one might assume would have a high effect on turnover (e.g., age, salary, career effect), those that rated highest included stress, emotional exhaustion (now commonly called compassion fatigue), lack of organizational commitment, and job satisfaction (Kim \& Kao, 2014). The impact of these staffing issues means that more families are stuck in a system that is not helping them.

\section{ICWA: a Dream Deferred}

The Indian Child Welfare Act (ICWA) of 1978 was passed in an attempt to break the cycle of AN/AI child removal. States were mandated to provide tribes with notice of child welfare involvement with an Indian family, invite tribes to intervene, and outline how tribes can assume jurisdiction of child protection proceedings (Indian Child Welfare Act P.L. 95-608, 1978). Additional components of ICWA were for state agencies to provide active efforts to prevent the break-up of an Indian family and reunify a family, and if a child has to be removed, then the state needed to keep children with extended family, a tribally approved foster home, an Indian foster home, or a tribally approved institution (Indian Child Welfare Act P.L. 95-608, 1978). If the child was not able to return to their parents, then the adoptive placement preferences were for the child to be with extended family, a tribal member, or any AN/AI family (Indian Child Welfare Act P.L. 95-608, 1978). The hope was to keep children connected to their culture, community, family, lands, and tribal nations (Haight et al., 2019; National Indian Child Welfare Association [NICWA], 2015). It is concerning that $\mathrm{AN} / \mathrm{AI}$ children continue to be disproportionately removed from 
their homes and that numerous court cases have challenged the main tenets of ICWA (Newman \& Fort, 2017).

In 2016, 38 years after the passage of ICWA, efforts were being made to improve state compliance with ICWA through the establishment of ICWA regulations, which clarified key elements of the policy like active efforts and notification requirements (Bureau of Indian Affairs, 2016). Efforts were also made to add ICWA data collection to the national AFCARS data collection system to better monitor state compliance; however, in May 2020, the Trump Administration rolled back data collection procedures for over 60 ICWA data points (National Indian Child Welfare Association, 2020). This lack of data collection makes it harder for the federal government and tribes to assess whether states are following the law.

Even with the good intentions of ICWA as a policy, it is embedded in an oppressive system that uses child removal as its primary intervention. Policy and funding drive child welfare practices. The US federal government will spend $\$ 5.7$ billion on foster care and $\$ 3.8$ billion on adoption in fiscal year 2021 compared to millions of dollars on prevention and kinship care services (Child Welfare League of America, 2020). States cannot and will not adequately prevent the break-up of an Indian family or provide active efforts to reunify under these funding mechanisms (ICW, 1978). This is another reason why child welfare systems have to drastically shift the theoretical frameworks that drive funding and child welfare practice.

\section{Stories of Child Welfare Oppression}

As part of a recent research study, 25 knowledge bearers of the Alaska child welfare system were interviewed, which included nine Alaska Native foster care alumni, ten Alaska Native relative caregivers, and six foster parents (Ullrich, 2020). Some of the knowledge bearers shared stories about a system that harmed them. The system perpetuates relational wounding through child removal and disconnects from important relationships in a child's life. The alumni shared how they experienced multiple forms of systemic related trauma through multiple placement changes and lack of key information about their extended family, culture, history, and identity (Ullrich, 2020). The alumni also expressed how the maltreatment they experienced was challenging, but the most distressful event was being separated from their siblings (Ullrich, 2020). The child welfare system's focus on providing safety through out-of-home care ignores the harms of removal from the child's perspective. It is not just the children that are removed from their parents. Through a child's eyes, the system is removing from them their siblings, parents, extended family members, community, cultural knowledge, history, and relational teachings that guide the development of a grounded identity. Every child needs to know who they are and where they come from. The current child welfare system not only disconnects children from others, but more importantly disconnects children from their true selves.

Many of the relative caregivers and foster parents also felt mistreated by the system (Ullrich, 2020). Very little information was provided about the children's backgrounds and their needs, and the caregivers felt that they were left on their own to fend for themselves (Ullrich, 2020). Many caregivers shared how they were expected 
to provide a therapeutic level of care for children that have been maltreated, without the support and compensation for it (Ullrich, 2020). Caregivers loved the children they provided care for and felt the depths of grief and loss when the child welfare system moved children with little notice or inclusion in decision-making processes. Once children were moved out of the caregivers' homes, many of them did not see or hear from the child again. Alumni also spoke about this disconnect compounding their sense of loss (Ullrich, 2020).

These important stories that were shared by the 25 knowledge bearers highlighted the need for child welfare to come to a racial and relational reckoning. Three main lessons were learned from the 25 knowledge bearers in this research study that aimed to learn about child wellbeing (Ullrich, 2020). First, we must acknowledge the traumas that child maltreatment and the child welfare system cause, so we can better assess for and prevent ongoing disconnect and relational wounding. Second, we need to ensure that children maintain relational continuity and connectedness for their wellbeing. And third, relational healing is important for children to develop a healthy relational identity that helps them be in right relationship with themselves and others. Action needs to be taken on these lessons learned for systemic transformation that stops the compounded harm of child removal.

It is not AN/AI or African American people's fault for the disproportionate social outcomes that we are seeing today. The child protection system has moved to the criminalization of inadequate parenting rather than the support of children and their families (Barbarin et al., 2020). Disproportionality exists because of traumatic government policies and harmful interventions that continue the cycles of disconnect and trauma. The US government has a responsibility to atone for the perpetration of historical traumas that have harmed generations of African American and AN/ AI children, families, and communities. What is problematic about child welfare is that the theoretical or conceptual foundation of policy and practice is missing key elements of Black and AN/AI epistemology, ontology, and axiology and ignores historical harms that clearly indicate a need for change.

\section{A Framework of Connectedness}

It is time to discontinue the unnecessary trauma that child removal causes and form a child welfare system that is based on community driven efforts and relationality. In a relational child welfare system, placement in stranger foster care would not be a standard operating procedure because it would be understood that from a child's perspective, it is not safe to be removed from everyone they love and every place they feel connected to generation after generation (Ullrich, 2020). The concept of child safety would expand to include the safety and wellbeing of the child's connectedness relationships with family, community, and environments because relationships are essential to everyone's wellbeing (Ullrich, 2020). Parents, children, and family would not be viewed as separate individuals; they are one unit that should no longer be disconnected from each other. When a child is relationally wounded from being removed, we would understand that this hurt is also felt by parents, extended 
family members, and community members because relationships are reciprocal, bidirectional, and interconnected.

Children need to maintain healthy connections and relationships with their family and community, so they feel safe, stable, and secure (Ullrich, 2020). Children need to know that people that care about them do not just disappear from their life or have contact 1-2 times per week, or once every four months if the child was moved to a different community that would require a plane ticket for contact to occur. In this next section, we present ideas on a framework for a re-imagined child welfare that could be based on an Indigenous Connectedness Framework that was updated after speaking with the twenty-five Alaska Native knowledge bearers from Ullrich's (2020) dissertation research study Fig. 1

The Indigenous Connectedness Framework highlights the main relationships and mechanisms for building and maintaining healthy relationships to family, community, environment, ancestors/future generations, culture/spirit, and self as a relational being (Ullrich, 2020). The red words represent the sources of trauma and challenges that we want to prevent from becoming mechanisms of disconnect (Ullrich, 2020). If these challenges do occur, it is important that the mechanisms of connectedness in the blue outer circle outweigh the challenges of disconnect so that a child maintains and develops a healthy relational identity, which is represented in the green inner circle (Ullrich, 2020). Children that have healthy relationships learn who they are and where they come from beyond colonial social constructs. Children that know who they are and where they come from do not need to adopt a trauma identity that keeps them protected in some ways, but locked in survival mode in other ways. Children that are raised with a relational identity become healthy adults, family members, and community members that help the next generation of children develop in a relational way.

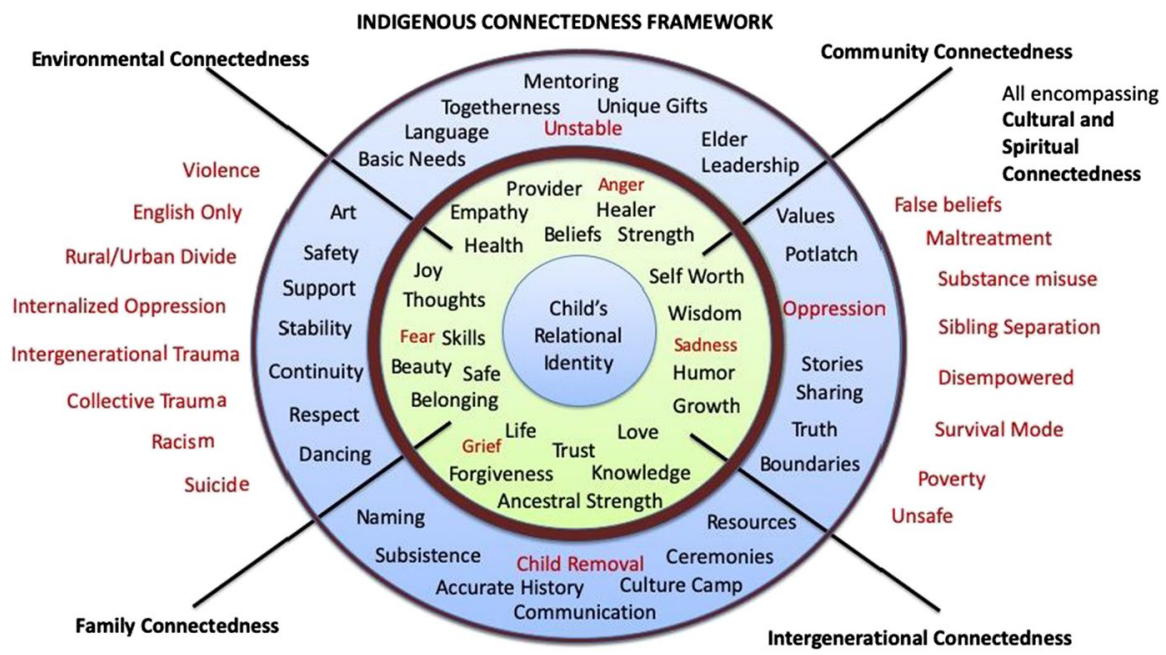

Fig. 1 Indigenous Connectedness Framework 


\section{The Application of Indigenous Connectedness for Practice and Policy Reform}

We combine the Indigenous Connectedness Framework and systems theory to provide a Connectedness Framework for Systems Change (Fig. 2). This framework includes suggested mechanisms of systems change which are identified within the concentric purple, blue, and green circles. These mechanisms of systems change have a relational effect on families, communities, the past/current/future generations, and the environment. Using a Connectedness Framework based on Indigenous concepts of relationality could lead to broader systems change in child welfare that better equips systems and communities with an ability to relate to children and families in a humanistic and culturally competent way.

This framework represents what is necessary for communities of color to thrive. In order for real change to occur, several mechanisms for change need to occur in unison. The historical trauma resulting from four hundred years of tyranny cannot be ignored because "the racial inequities created during the colonial period influenced the founding of the Nation" (LaVeist et al., 2019). Even as Thomas Jefferson was berating the practice of slavery, he owned hundreds of slaves himself (Vinn, 2003). The Tulsa Massacre was not listed in history books but was a significant and tragic event in America's oppression of communities of color (Johnson, 2020). This ignorance of history ignores the traumatic impacts of created child welfare policies and practices.

Congress must be willing to appropriate the funding necessary to support building strong communities, with sufficient wholistic resources, mental health, physical health, public safety, education, food sufficiency, and adequate housing to address the needs of low-resourced communities. Funding appears on

\section{A CONNECTEDNESS FRAMEWORK FOR SYSTEMS CHANGE}

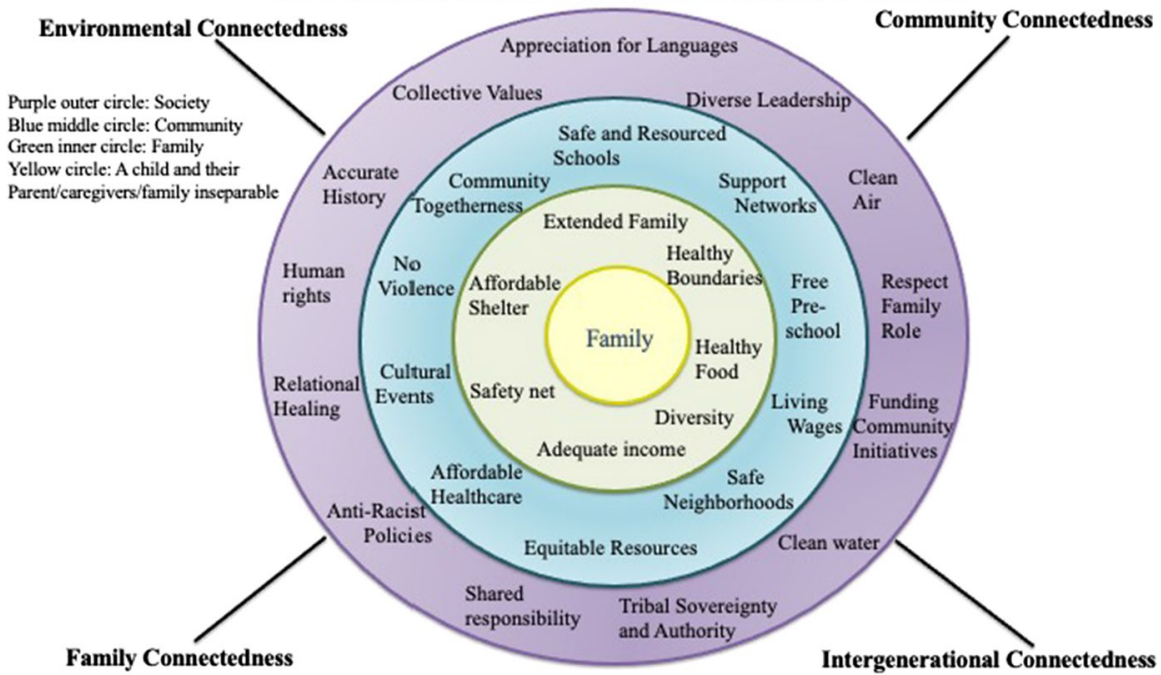

Fig. 2 A connectedness framework for systems change 
both national and state levels, to become available in times of crisis rather than as prevention methods. As recent as February 25, 2021, H.R. 1377, the Emergency Funding for Child Protection Act, was introduced in the 117th Congress (GovTrack, 2021). This Act was in response to the COVID-19 crisis and provides grants to states to "expand services, provide support to community-based organizations, purchase emergency supplies, and provide temporary direct payments to families caring for children under protective services supervision that are awaiting approval for government assistance, among other uses. The bill does not require states to match funding under these grants (GovTrack, 2021). However, states set the tone and direction for positive change to accompany that funding.

Let us take a closer look at the cost of inaction. A 2012 study focused on confirmed child maltreatment cases-1,740 fatal and 579,000 non-fatal-for a 12-month period (Fang et al., 2012). The lifetime cost for each fatal case of child abuse was approximately $\$ 1.3$ million (Fang et al., 2012). These calculations factored into the income a child would have earned had he or she reached adulthood and participated in the workforce. Peterson et al. (2018) estimated the cost per victim of nonfatal child maltreatment to be $\$ 760,000$, the cost of fatal child maltreatment nearly twice that figure. If we do the math, it becomes clear that funding healthy, strong communities, as they were conceptualized by Melton (2009), would be a cheaper and more effective alternative. What if initiatives like Melton's strong communities had been funded to focus on building healthy, resilient communities where children could thrive and where parents could seek help with fear of retaliation? We know that funding to prevent something from happening is difficult to justify, but child fatalities are permanent; they cannot be reversed.

Understanding child maltreatment as a public health problem could pave the road to prevention. Systems respond differently to a public health crisis than to a criminal justice issue, and families respond differently to a public health person than to someone from the child protection agency. We have seen past initiatives that were set in a public health framework be effective in high risk and low resourced communities. Michigan initiated an infant mental health home visitation model (IMH-HV) in 1977. Therapists are cognizant that establishing a working relationship is critical to the IMH-HV being successful (Weatherston \& Ribaudo, 2020). However, home visitation models require trust in order to build working relationships. Communities of color have not found trust to be an effective communication link with governmental agencies.

Employing community outreach workers who are part of the community in which they work. Having familiarity with the community's "personality" makes a difference when attempting to build trust. In an article on child safety and family support, Melton (2009) stated "Perhaps now more than ever, for the sake of our own and our neighbors' families, we need a rebirth of community." However, even defining a community may not be as easy as it seems. Context, geographical boundaries, and the design of the neighborhood all play an important part when trying to define community. When researchers compare neighborhoods and the disparities of resources in some versus others, the racial and ethnic composition becomes part of the discussion. 
Can the interface of child protection agencies with communities of color be changed? If families of color are to have any trust in a government system that has the ability to remove their children from their care, the system's first interaction with the community agency has to be to provide resources, not remove children. A worker from the investigation unit is usually the first contact with a child protection agency. If community outreach workers made regular contact with families, and if sections of government buildings were opened to evening community meetings and were viewed as belonging to the community, the perception of those systems could change. Innovative strategies have been tried in various places throughout the USA and with some success when strong communities was implemented in Greenville, SC, and in selected communities in Israel (Kimbrough-Melton \& Melton, 2015). Neighborhoods have changed over the years. Families used to know their neighbors and could count on them in emergency situations, but also as a support network. A revitalization of neighborhoods needs to occur.

Child protection workers with training in working with multicultural populations are needed for communities of color. Language is an important factor in establishing communication with a client. Child protection workers need to practice and apply cultural humility and trauma informed care to better engage with families and the community in a positive way rather than reinforce the power/privilege divide that is so noticeable. Proper training, evaluation, and supervision can ensure that what is learned in training is maintained in practice.

\section{Preventing Removal Is Possible}

The federal budget needs to drastically shift child welfare funding from foster care and adoption to in-home services, family treatment, and kinship care. For example, more funding should be put in place to allow child welfare workers to spend more time with families and provide in-home services. Assisted living homes could be created to temporarily take in whole families, while parental issues are addressed. The majority of families involved with child welfare struggle with poverty, substance use, and mental health issues, so family treatment options that are relationally based and allow children to remain with their parents need to be bolstered (Blackstock \& Trocmé, 2005). If a child needs to be temporarily placed out of the home, then kinship care is a safety net for ensuring that a child is not completely removed from their parents, extended family, family history, and cultural/spiritual knowledge (Ullrich, 2020). Placement with family should be seen as a connectedness placement, rather than child removal into stranger foster care that disconnects a child from their important relationships.

Re-imagining child welfare involves making a community and relational shift as the guiding framework. Through this lens, child protection would be seen as a shared responsibility among community members and community organizations. For example, Alaska Native communities such as Kwigillingok created their own child protection team to help families and prevent child abuse and neglect (Hillman, 2016). This village child protection team designed their intervention based on Indigenous Elder's knowledge and guidance and brought the number of children removed 
down to zero in their community in less than 2 years (Hillman, 2016). The Kwigillingok community provides an example of a child protection intervention that does not necessarily involve child removal.

Over the past few decades, there have been "pockets of excellence" where systems have come together and collaborated across their defined areas of responsibility, to create a workable and somewhat welcoming system for children and their families. Melton and a few colleagues who saw the repressive nature of the child protection system in so many states created an initiative called Strong Communities for Children (Melton, 2009; Melton \& Anderson, 2008; Melton \& Thompson, 2002). This initiative focused on a community-wide promotion of family and community wellbeing. Melton realized that the protection of children had to become a part of everyday life and in all the places and environments where there were children (Kimbrough-Melton \& Melton, 2015). With replication of this initiative in a few states and even in Israel, the process has proven effective. While the fact that community engagement works is not a secret, strong communities goes a step further and focuses on promoting healthy community-wide development. It is concerning that there has not been a national commitment to implement community-based child welfare. To create healthy communities that foster and maintain minorityfriendly child protection systems, the following ingredients must be present.

\section{Conclusion}

Our discussion leads us to the following recommendations considering the history, disproportionality, and need for a different approach to child welfare:

- Oppressed populations should have a legally recognized role in designing culturally appropriate and relational systems of care to assure the safety of their children.

- Federally recognized tribes should be able to design and implement their own child protection systems.

- Tribal courts should have jurisdiction over child protection.

- Neighborhoods need to be revitalized.

- Individuals and families should not live in fear of being the targets of violence and of having their children removed by a system they do not understand how to navigate.

- Funding for programs like strong communities, and community child protection teams that have proven to be effective, should become a reality.

- All systems need to be built upon a relational framework that guides communitydriven efforts, includes the wisdom of lived experience, and provides action steps to end disproportionality of outcomes for children of color.

If the above recommendations were implemented, we would change the landscape of the USA for the betterment of its children. The USA can have a system of protection for children and families that is welcoming to all. Child welfare needs to be a relationally based system, where relational wounding stops and relational 
healing begins. The connectedness framework provides guidance on the actions needed to create a paradigm shift within child welfare and all systems that interface with children. Systemic change takes time and effort. The current generation of children do not have that luxury of time.

\section{Declarations}

Conflict of Interest The authors declare no competing interests.

\section{References}

Banahene, A., \& Minka, E. (2018). Black parents ask for a second look: Parenting under "White" child protection rules in Canada. Children and Youth Services Review, 94, 511-524. https://doi.org/10. 1016/j.childyouth.2018.08.030

Barbarin, O., Tolan, P., Gaylord-Harden, N., \& Murry, M. (2020). Promoting Social Justice for African American boys and young men through research and intervention: A challenge for developmental science. Applied Developmental Science, 24(3), 196-207. https://doi.org/10.1080/10888691.2019. 1702880

Blackstock, C., \& Trocmé, N. (2005). Community-based child welfare for Aboriginal children: Supporting resilience through structural change. Social Policy Journal of New Zealand, 24(12), 12-33.

Brave Heart, M. Y. H., Chase, J., Elkins, J., \& Altschul, D. B. (2011). Historical trauma among indigenous peoples of the Americas: Concepts, research, and clinical considerations. Journal of Psychoactive Drugs, 43(4), 282-290. https://doi.org/10.1080/02791072.2011.628913

Bureau of Indian Affairs. (2016). Guidelines for implementing the Indian Child Welfare Act. https:// www.federalregister.gov/documents/2016/12/30/2016-31726/guidelines-for-implementing-theindian-child-welfare-act

Child Welfare League of America (2020). The president's fiscal year 2021 budget request. https://www. cwla.org/wp-content/uploads/2020/02/CWLA-Summary-of-Presidents-FY-2021-Childrens-ChildWelfare-Budget.pdf

Children's Bureau (2021). Child maltreatment 2019. https://www.acf.hhs.gov/cb/report/child-maltreatme nt-2019

Cross, T. L. (2014). The Indian Child Welfare Act: We must still fight for our children. Reclaiming Children \& Youth, 23(2), 23-24.

Dettlaff, A. J., \& Boyd, R. (2020). Racial disproportionality and disparities in the child welfare system: Why do they exist, and what can be done to address them? The Annals of the American Academy of Political and Social Science, 692(1), 253-274. https://doi.org/10.1177/0002716220980329

Dunbar-Ortiz, R. (2014). An indigenous peoples' history of the United States (3rd ed.). Beacon Press.

Fang, X., Brown, D., Florence, C., \& Mercy, J. (2012). The economic burden of child maltreatment in the United States and implications for prevention. Child Abuse \& Neglect, 36(2), 156-165. https://doi. org/10.1016/j.chiabu.2011.10.006

Gottlieb, C. (2021). Black families are outraged about family separation within the U.S. It's time to listen to them. Time Magazine https://time.com/5946929/child-welfare-black-families/

GovTrack (2021). S. 462: Emergency funding for Child Protection Act. https://www.govtrack.us/congr ess/bills/117/s462/summary

Guzman, A., Carver-Roberts, T., Leake, R., \& Rienks, S. (2020). Retention of child welfare workers: Staying strategies and supports. Journal of Public Child Welfare, 14(1), 60-79. https://doi.org/10. 1080/15548732.2019.1683121

Haaland, D. (2021). Opinion: Deb Haaland: My grandparents were stolen from their families as children. We must learn about this history. The Washington Post. https://www.washingtonpost.com/opinions/ 2021/06/11/deb-haaland-indigenous-boarding-schools/

Haight, W., Waubanascum, C., Glesener, D., Day, P., Bussey, B., \& Nichols, K. (2019). The center for regional and tribal child welfare studies: Reducing disparities through indigenous social work 
education. Children and Youth Services Review, 100, 156-166. https://doi.org/10.1016/j.childyouth. 2019.02.045

Halloran, M. (2019). African American health and post traumatic slave syndrome: A terror management theory account. Journal of Black Studies, 50(1), 5-65. https://doi.org/10.1177/0021934718803737

Hillman, A. (2016). AK: Protecting a village. Alaska Public Media https://www.alaskapublic. org/2016/04/22/ak-protecting-a-village/.

Hirshberg, D., Sharp, S., \& Hill, A. (2005). Thirty years later, the long-term effect of boading schools on Alaska Natives and their community. Anchorage: AK, Institute of Social and Economic Research, University of Alaska Anchorage.

Hopkins, R. (2013). Sexual trauma: One legacy of the boarding school era. Indian Country Today. http://indiancoun try to daymedianetwork.com/opinion/sexual-trauma-one-legacy-board ing-school-era-148455

Indian Child Welfare Act P.L. 95-608 (1978), http://www.nicwa.org/Indian_Child_Welfare_Act/ICWA. pdf

Johnson, H. (2020). Tulsa, then and now: Reflections on the Legacy of the 1921 Tulsa Race Massacre. Great Plains Quarterly, 40(3), 181-185.

Kim, H., \& Kao, D. (2014). A meta-analysis of turnover intention predictors among US child welfare workers. Children and Youth Services Review, 47, 214-223. https://doi.org/10.1016/j.childyouth. 2014.09.015

Kimbrough-Melton, R. J., \& Melton, G. B. (2015). "Someone will notice, and someone will care": How to build strong communities for children. Child Abuse \& Neglect, 41, 67-78. https://doi.org/10. 1016/j.chiabu.2015.02.015

LaVeist, T., Fullilove, M., \& Fullilive, R. (2019). 400 years of inequality since Jamestown of 1619. A merican Journal of Public Health, 83-84. https://doi.org/10.2105/AJPH.2018.304824.

Leary, J. (2005). Post traumatic slave syndrome: America's legacy of enduring injury and healing. Uptone Press.

Melton, G. B. (2009). How strong communities restored my faith in humanity: Children can live in safety. In K. A. Dodge \& D. L. Coleman (Eds.), Preventing Child Maltreatment (pp. 82-101). Community Approaches.

Melton, G. B., \& Anderson, D. (2008). From safe sanctuaries to strong communities: The role of communities of faith in child protection. Family \& Community Health, 31, 173-185. https://doi.org/10. 1097/01.FCH.0000314577.48603.b0

Melton, G. B., \& Thompson, R. A. (2002). The conceptual foundation: Why child protection should be neighborhood-based and child-centered. In G. B. Melton, R. A. Thompson, \& M. A. Small (Eds.), Toward a child-centered, neighborhood-based child protection system (pp. 3-27). Praeger.

Messer-Kruse, T. (2020). What the 1619 project really means: Its liberal and conservative critics both miss the point. The Chronicle of Higher Education, (66)25. https://www.chronicle.com/article/ what-the-1619-project-really-means/

Napoleon, H. (1996). Yuuyaraq: The way of the human being: With commentary. Alaska Native Knowledge Network, University of Alaska, Fairbanks.

National Indian Child Welfare Association (2015). Setting the record straight: The Indian Child Welfare Act Fact Sheet. https://www.nicwa.org/wp-content/uploads/2017/04/Setting-the-Record-StraightICWA-Fact-Sheet.pdf

National Indian Child Welfare Association (2020). HHS final AFCARS rule impacts data collection for American Indian and Alaska native children. https://www.nicwa.org/latest-news/afcars-data-colle ction-for-native-children/

National Native American Boarding School Healing Coalition. (n.d.) Para. 2. https://boardingschoolhealing.org/education/us-indian-boarding-school-history/

Newman, M., \& Fort, K. (2017). Legal challenges to ICWA: An analysis of current case law. Child Law Practice, 36(1), 13-15.

Office of Children's Services (2020). Out-of-home care statistics. http://dhss.alaska.gov/ocs/Pages/stati stics/default.aspx

Peterson, C., Florence, C., \& Klevens, J. (2018). The economic burden of child maltreatment in the United States, 2015. Child Abuse \& Neglect, 86, 178-183. https://doi.org/10.1016/j.chiabu.2018.09. 018

Powers, M., \& Faden, R. (2006). Social justice: The moral foundations of public health and health policy. Oxford University Press. 
State of Alaska Department of Labor (2019). Population estimates. https://live.laborstats.alaska.gov/pop/ index.cfm

Tribal Law Updates. (2001). Apology from Child Welfare League of America. https://tlpi.wordpress. com/2011/08/11/apology-from-child-welfare-league-of-america/

U.S. Advisory Board on Child Abuse and Neglect. (1990). Child abuse and neglect: Critical first steps in response to a national emergency. U.S. Government Printing Office.

U.S. Advisory Board on Child Abuse and Neglect. (1991). Creating caring communities: Blueprint for an effective federal policy on child abuse and neglect. U.S. Government Printing Office.

U.S. Advisory Board on Child Abuse and Neglect. (1993). Neighbors helping neighbors: A new national strategy for the protection of children. U.S. Government Printing Office.

Ullrich, J. S. (2020). Indigenous connectedness as a framework for relational healing within Alaska Native Child Welfare (Doctoral dissertation). https://digital.lib.washington.edu/researchworks/handle/1773/45544

Weatherston, D. J., \& Ribaudo, J. (2020). The Michigan collaborative for infant mental health research. The Michigan infant mental health home visiting model. Infant Mental Health Journal, 41, 166177. https://doi.org/10.1002/imhj.21838

White Hawk, S. (2006). Adoption was no salvation. Colorlines, 9(2), 36-37.

Wildeman, C., \& Emanuel, N. (2014). Cumulative risks of foster care placement by age 18 for U.S. children, 2000-2011. PLoS One, 9(3), 1-7. https://doi.org/10.1371/journal.pone.0092785

Wolfe, B. (2021). Slave ships and the middle passage. In Encyclopedia Virginia. https://encyclopediavir ginia.org/entries/slave-ships-and-the-middle-passage

Publisher's Note Springer Nature remains neutral with regard to jurisdictional claims in published maps and institutional affiliations. 